\title{
Research on Injection Process Simulation of Microbial Flooding in Baolige Oilfield
}

\author{
Jiliang $\mathrm{Yu}^{1, \mathrm{a}}$, Yongbin $\mathrm{Li}^{2, \mathrm{~b}}$, Suzhen Guo ${ }^{3, \mathrm{c}}$, Shasha Liu, Rui Wang, Lisha \\ Duan, Ai Wang \\ ${ }^{1}$ Petroleum Production Engineering Research Institute, Huabei Oilfield Company, \\ Renqiu ,Hebei062552, china \\ ${ }^{2}$ Petroleum Production Engineering Research Institute, Huabei Oilfield Company, \\ Renqiu ,Hebei062552, china \\ ${ }^{3}$ Petroleum Production Engineering Research Institute, Huabei Oilfield Company, \\ Renqiu ,Hebei062552, china \\ aemail:cyy_yujil@petrochina.com.cn, bemail:cyy_liyb@petrochina.com.cn, \\ cemail:cyy_gsz@petrochina.com.cn
}

\begin{abstract}
Keywords: Microbial enhanced oil recovery; physical simulation experiment;Heavy oil reservoir with low temperature; Microbial field.

Abstract. Aiming at the issues in microbial flooding process of Baolige oilfield, the following points were deeply studied in this paper indoor physical simulation experiments, the effect of different flooding ways on enhance oil recovery, the relationship between output bacterial concentration and injected bacteria concentration and influence of nutrient solution concentration on maintaining the produced fluid concentration of bacteria. The results showed that the microbial flooding by injecting $1 \%$ bacterial fluid plus $1 \%$ nutrient solution can enhance $16.77 \%$ oil recovery. And the produced fluid can further enhance oil recovery by $5.74 \%$ when supplemented nutrient solution \& bacterial fluid and ferment about 10-12h before keep on microbial continuous flooding, and the produced fluid bacteria concentration can reach $10^{8}$ cells $/ \mathrm{mL}$ or more. However, due to the adsorption of cell core on microbial and the core permeability effect on microbial migration, the concentration of produced bacteria fluids was always one order of magnitude lower than the concentration of injected bacteria fluids. Using the produced fluids reinjection added above $0.25 \%$ nutrient solution, the concentration of produced bacteria fluids can be maintained at $10^{7}$ cells $/ \mathrm{mL}$ or more. The results can provide technical support for on-site inject program design.
\end{abstract}

\section{Introduction}

The heavy oil reservoir with low temperature in Baolige oilfield is in the conventional injection-production well pattern development. After the industrial application of microbial flooding was carried out since 2010, the microbial field was preliminary built and maintained stably, achieving the goal of stabilizing production at annual output of 250,000 tons. Although the application effect of the scene has been made, from the goal of improving oil recovery, more works can be done. In order to verify the microbial effect, improve continuous optimization measures in the field and support for the injection technology research and project design, further indoor physical simulation experiments are carried out $[1-7]$.

\section{Overview of Baolige oilfield}

Baolige oilfield is located in the west of East Ujimqin Bannereast in Inner Mongolia autonomous region, of which geologic structure is in Bayindulan Sag north Sub-sag of Erlian Basin. In November 2001, Baolige oilfield was developed with injecting water. Now 4 blocks, Ba19, 38, 48, 51, are in development which are lithologic-structural reservoir. The development way of Baolige oilfield is the conventional injection pattern, of which the formation porosity is $13.4 \% \sim 21.7 \%$, permeability is 
$123.4 \sim 169.2 \mathrm{mD}$, crude oil freezing point is $29{ }^{\circ} \mathrm{C}$, wax content is $10.7 \% \sim 10.8 \%$, colloid and asphaltene content is $46.0 \% \sim 51.2 \%$, the viscosity of crude oil is $1,000 \sim 2,000 \mathrm{mPa} \cdot \mathrm{s}$ under the formation conditions. The oil-water viscosity ratio is high $(34 \sim 800)$ and fingering leads to low waterflood efficiency. The water cut rising rate reaches to $20 \%$, leading to serious water breakthrough. Part of the heavy oil reserves is difficult to produce effectively, causing poorer overall development effect.

\section{Physical simulation experiment}

Core loading.Quartz sand of 80, 120 and 200 mesh are mixed according to a certain proportion and loaded to 4 cores respectively of which diameter is $2.5 \mathrm{~cm}$, length is $110 \mathrm{~cm}$. And then these cores are saturated with clean injection water after vacuumed in turn, to measure porosity, permeability and saturation of theses cores. The dehydrated crude oil of Ba 19 block is injected to the core tube and aged for 7 days under formation temperature. The measurement method of porosity and permeability is: core tube is vacuumed for 6 hours after the mechanical loading, at the same time the core is saturated with formation water, finally porosity and permeability are calculated according to the total volume of the formation water into the core tube and differential of the import and export [8]. Core parameters are shown in table 1.

Table 1 Experiment core parameters

\begin{tabular}{cccccc}
\hline $\begin{array}{c}\text { Core } \\
\text { Number }\end{array}$ & $\begin{array}{c}\text { porosity } \\
\%\end{array}$ & $\begin{array}{c}\text { Permeability } \\
\mathrm{mD}\end{array}$ & $\begin{array}{c}\text { Water } \\
\text { Saturation } \\
\%\end{array}$ & $\begin{array}{c}\text { Oil Saturation } \\
\%\end{array}$ & $\begin{array}{c}\text { Crude oil } \\
\text { viscosity } \\
\mathrm{mPa} \cdot \mathrm{s}\end{array}$ \\
\hline 0 & 38.5 & 131.4 & 5.5 & 80 & 1155 \\
1 & 30.6 & 118.2 & 4.9 & 80 & 1155 \\
2 & 34.7 & 121.5 & 5.3 & 80 & 1155 \\
3 & 32.3 & 119.7 & 5.1 & 80 & 1155 \\
\hline
\end{tabular}

Experiment steps of physical simulation. (1) First, the loaded core stopped being driven by water until the water cut of core outlet reached $98 \%$. The temperature is formation temperature $58{ }^{\circ} \mathrm{C}$. The total injection is $0.82 \mathrm{PV}$.

(2) Add bacterium liquid of $1 \%\left(10^{6} \sim 10^{7}\right.$ cells $\left./ \mathrm{mL}\right)$ and nutrient solution of $1 \mathrm{PV}$ to the core, and the injection rate was $0.5 \mathrm{~mL} / \mathrm{min}$. Then close the valve on both ends and cultured for 5 days, followed by microbial flooding. Monitor the change of bacteria concentration in produced fluid and oil recovery.

(3) Output liquid of microbial flooding was continued to recycle to the core to displace oil after removing oil. In order to improve the concentration of injection bacterial, the produced fluid was supplemented with nutrient solution in a certain concentration and bacteria liquid and then fermented for 12 hours. After injecting 2.38 PV, the injection bacterial concentration increased to more than $10^{8}$ cells $/ \mathrm{mL}$.

(4) The produced fluid was used in the oil displacement experiments after being added nutrient solution of $1 \%, 0.25 \%$ and $1 \%$ respectively. Each concentration was injected with $0.6 \mathrm{PV}$. The changes of the bacteria concentration and recovery factor were monitored in the core outlet end.

\section{The experimental results and analysis}

The influence of different displacement medium on recovery.From Fig. 1, if bacteria liquid of $1 \%$ and nutrient solution of $1 \mathrm{PV}$ were injected after water flooding, the bacteria concentration of output liquid increased significantly, and maintained between $10^{5}$ and $10^{6}$ cells $/ \mathrm{mL}$, but it is difficult to improve furthermore, which verifies the site condition. The calculated recovery can be increased by $16.77 \%$ on the basis of water flooding efficiency. In the microbial flooding, output fluid is continued to the microbial flooding continuously after supplemented nutrient solution and bacteria liquid and then fermented for $10 \sim 12$ hours. The concentration of injecting bacteria can reach more than $10^{8}$ cells $/ \mathrm{mL}$ after complementing nutrient solution and fermentation. Along with the increase of the injecting 
bacteria concentration, the recovery efficiency can be improved by $5.74 \%$ more than that of not cultivating. At the same time, the bacteria concentration in produced fluid can remain above $10^{7}$ cells $/ \mathrm{mL}$. After the water cut reaches $98 \%$, the calculated recovery can be increased by $14.21 \%$ on the basis of microbial flooding. The above results show that the recovery factor can be improved effectively by increasing the concentration of injection bacterial.

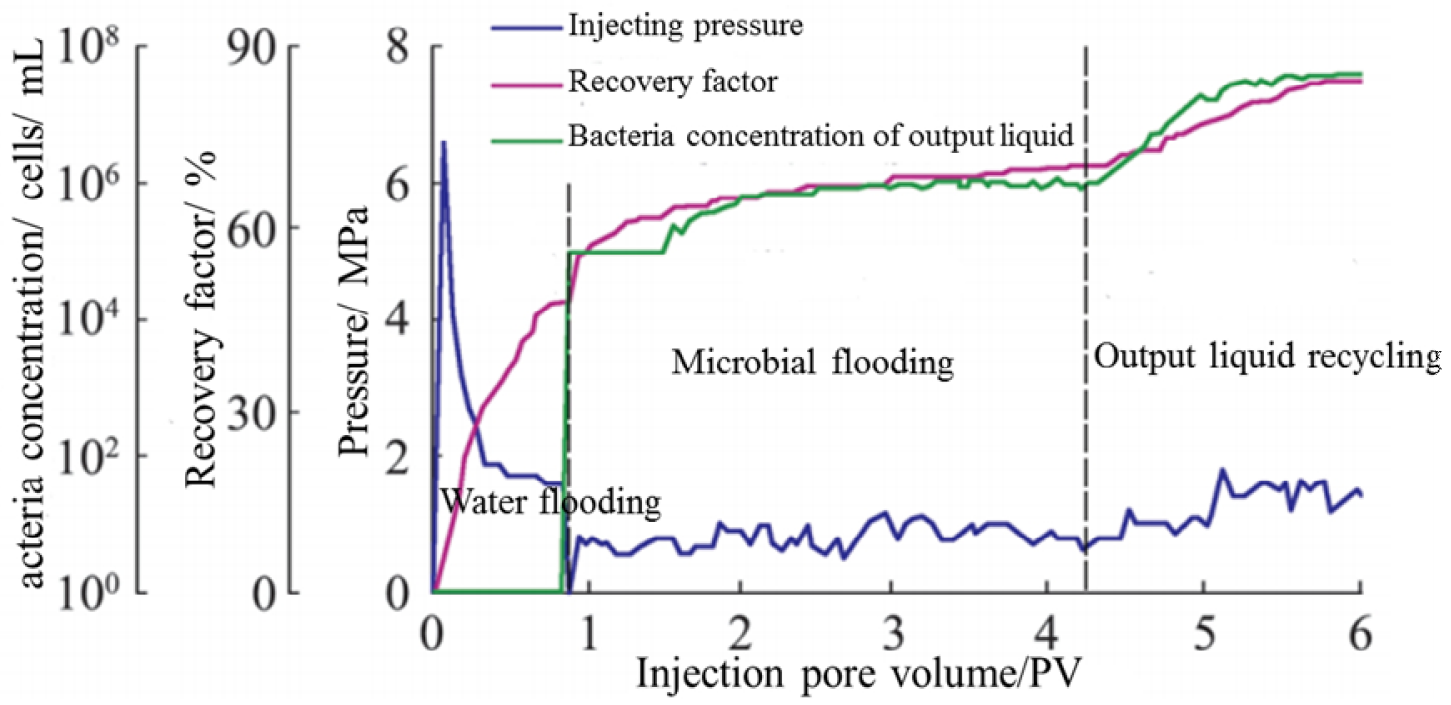

Fig.1 The relationship between recovery factor and bacteria concentration, injection PV number

The relationship of bacteria concentration between output and injection. The bacterial concentration of injection wells may reach $10^{8}$ cells $/ \mathrm{mL}$. But in the condition that there is no large channel in the formation, bacteria concentration of output liquid in oil wells can only remain at $10^{6}$ cells $/ \mathrm{mL}$ around normally. In order to determine the causes of this phenomenon, the relationship of bacteria concentration between output and injection was studied through the indoor physical simulation experiment. The liquid concentration is fixed at $1 \%$, microbial flooding is carried out by increasing the concentration of nutrient solution in turn, at the same time the changes of injection bacteria concentration and produced fluid concentration is monitored, the results are shown in Fig. 2.

From Fig. 2, in the condition of injection allocated with formation water and fixed bacteria liquid concentration with $1 \%$, when adding nutrient solution of $0.25 \%$ in the early years of the microbial flooding, the concentration of injection bacterial maintained at $10^{6}$ cells $/ \mathrm{mL}$, but the concentration of output bacteria was only $10^{5}$ cells $/ \mathrm{mL}$; When the nutrient solution concentration was increased to $0.5 \%$, the concentration of injecting bacteria and output bacteria have been obviously improved, increased by one order of magnitude respectively. But when continuing to increase the nutrient solution concentration, the concentration of injecting bacteria and output bacteria remain unchanged, difficult to further improve. Considering that the core used in the experiment is short and the injected nutrient solution and bacteria liquid stay shorter in core column, so the bacteria liquid of $1 \%$ and nutrient solution of $1 \%$ were fermented for 8 hours before microbial flooding. The results showed that the concentration of injection bacterial increased to more than $10^{8}$ cells $/ \mathrm{mL}$, and bacteria concentration in the produced fluid also increased, but only up to about $10^{7}$ cells $/ \mathrm{mL}$. The above results show that the injection and production bacteria concentration can be improved by increasing the concentration of nutrient solution, but due to the effect of adsorption of the core to bacteria and the influence of core permeability on the microbial migration, bacteria concentration in the produced fluid is always lower than that of injection with more than one order of magnitude. Even though the injection bacteria concentration is extremely high, the bacteria concentration of output liquid is unlikely to reach $10^{8}$ cells $/ \mathrm{mL}$, unless a large channel is formed. This conclusion is consistent with the field monitoring result, further illustrating that the bacteria concentration is difficult to improve further more. 


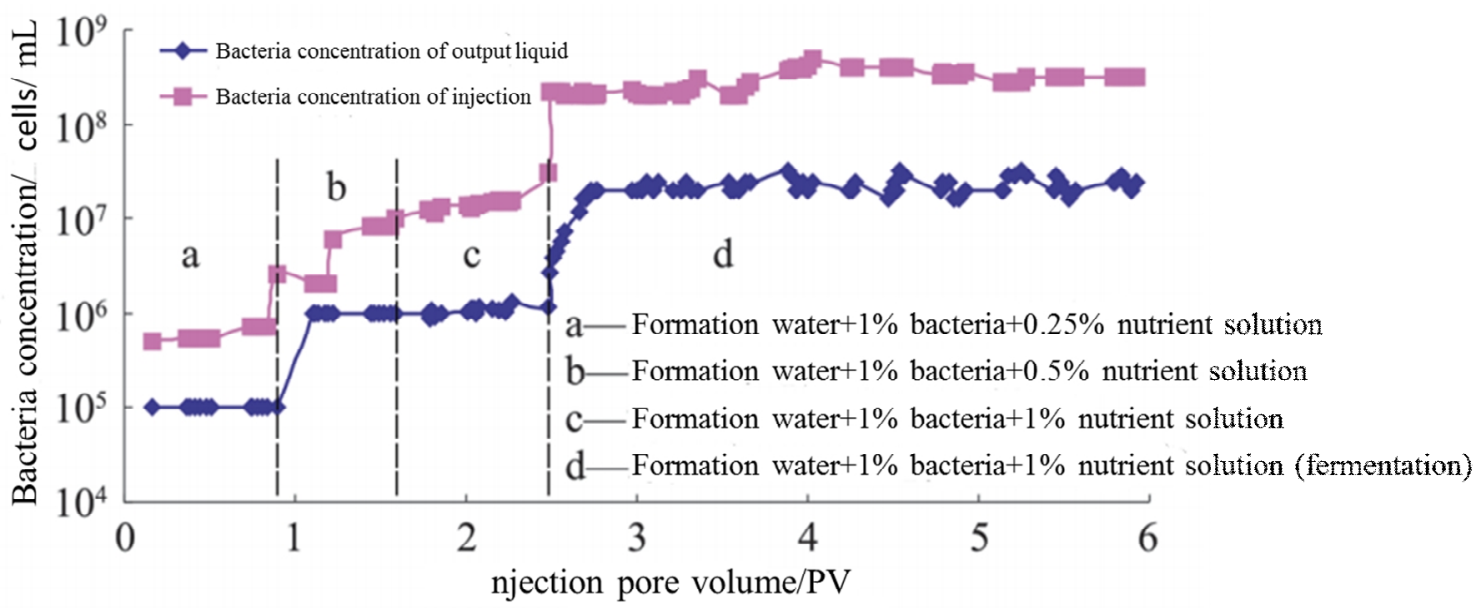

Fig.2 The changes of bacteria concentration of injection and production

The effect of nutrient solution concentration on maintaining bacteria concentration of output liquid.Through field monitoring of the whole microorganisms of Baolige oilfield, it finds that after two rounds of microbial flooding, bacteria concentration in produced fluid can remain at $10^{6}$ cells $/ \mathrm{mL}$ around. And the injected target bacteria have become the dominant microorganism, forming the stable microbial field gradually. But the cost of plug injection of nutrients of $1 \%$ and bacteria liquid to maintain microbial field is higher. If the complement of only nutrient solution can reach the purpose of stabilizing microbial field, the cost can be greatly reduced. To complement nutrient solution of different concentration in produced fluid, the influence of reinjection on produced fluid bacteria concentration is studied through indoor physical simulation experiment. The results are shown in Fig. 3.

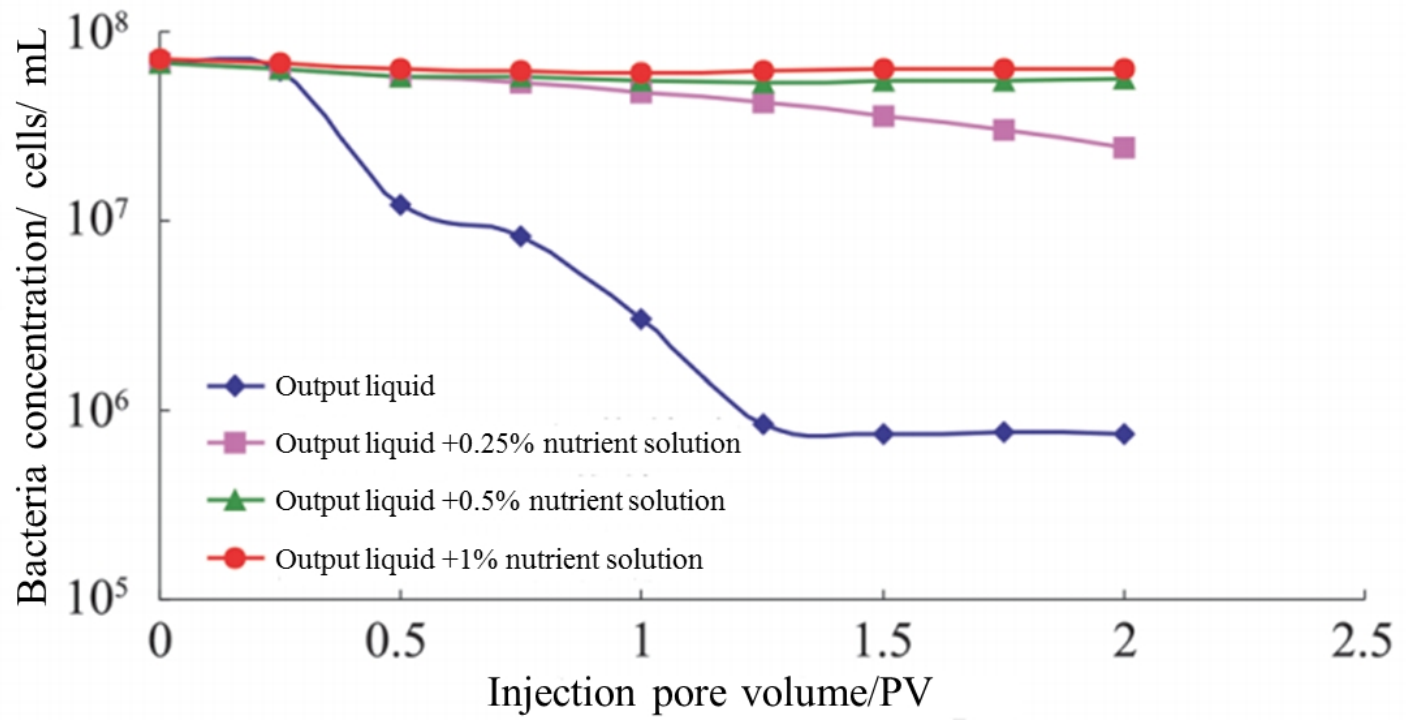

Fig. 3 The changes of bacteria concentration in different nutrient solution concentration

From Fig. 3, if not complementing nutrient solution, the number of microorganisms in produced fluid is declining, hard to remain above $10^{6}$ cells $/ \mathrm{mL}$. This is due to a lack of nutrients in microorganism leading to slow growth and continuous adsorption of microorganisms on core. When the nutrient solutions of different concentrations are added to the reinjected output fluid, microbial concentration detecting at the core outlet decreases obviously slow. When the nutrient solution concentration is more than $0.25 \%$, bacteria concentration of produced fluid at outlet can remain above $10^{7}$ cells $/ \mathrm{mL}$.

\section{Conclusions}

(1) Add the appropriate proportion of microbes and nutrient solution to the formation, recovery factor of crude oil will be improved on the basis of water drive. It shows that microorganisms can 
effectively improve the oil properties of Baolige oilfield, increase liquidity of crude oil in the formation and enhance oil displacement effect.

(2) The injection process which produced sewage is reinjected to the formation after being added with nutrient solution and proliferated can effectively increase microbial injection concentration, improve oil recovery, extend the action cycle of microorganisms, reduce the injection cost and give significant guidance to the development of similar reservoir.

(3) The experiment mainly aims at Ba19 block of Baolige oilfield to research oil property. In order to verify the validity of the results, it needs to carry out long-core simulation experiment and field test.If you follow the "checklist" your paper will conform to the requirements of the publisher and facilitate a problem-free publication process.

\section{Acknowledgements}

This work was financially supported by National Natural Science Foundation of China (51174092/E0403), Key S\&T Special Projects of PetroChina Company Ltd. "Key technology research and application for increasing production and stable yields of 8 million tons in Huabei oilfield" (Project number 2014E-3507)and Major Science and technology project of Huabei Oilfield Company (2011-HB-Z230).

\section{References}

[1] LI J, LIU J S, TREFRY M G, et al. Interactions of microbial-enhanced oil recovery processes [J]. Transport in Porous Media, 2011, 87(1): 77-104.

[2] NERURKAR A S, SUTHAR H G, DESAI A J. Biosystem Development for Microbial Enhanced Oil Recovery (MEOR) [M]. Microorganisms in Sustainable Agriculture and Biotechnology, 2012(2): 711-737.

[3] BRYANT E S, DONALDSON E C, YEN T F, CHILINGARIAN G V, The in situ microbial enhanced oil recovery in fractured porous media $[\mathrm{J}]$. Journal of Petroleum science and engineering, 2007, 58: 161-172.

[4] ZHANG Ting-shan, REN Ming-zhong, LAN Guang-zhi, et al. Microbial Degradation Influences on Heavy Oil Characters [J]. Journal of Southeast Petroleum Institute, 2003, 25 (5): 1-4.

[5] LI Mu, YANG Hong. Experiment Study of Microbial Surfactant in Devisofying Emulsified Heavy Oil [J]. Special Oil \&Gas Reservoirs, 1999, 4(6): 53-58.

[6] CHENG Chang-ru, ZHANG Shu-qin, YAN Yun-gui, et al. Application of microbial injection for oil recovery enhancement [J] . Oil Drilling \&Production Technology, 2006, 28(6): 46-50.

[7] LIU Tao. Study on Migration of Activator and Growth of Microbe in Simulated Reservoir Condition [D]. Qing Dao: Ocean University of China, 2010.

[8] ZHANG Ting-shan, LAN Guang-zhi, DENG Li, et al. Experiments on Heaving Oil Degradation and Enhancing Oil Recovery by Microbial Treatments [J]. Acta Petrolei Sinica, 2001. 